UNDERGRADUATE RESEARCH IN NATURAL AND CLINICAL SCIENCE AND TECHNOLOGY (URNCST) JOURNAL Read more URNCST Journal articles and submit your own today at: https://www.urncst.com

\title{
Palliative Care Management System
}

\author{
Saman Arif, BSc [1]*, Tong Li, BSc [1], Pooya Moradian Zadeh, PhD [1] \\ [1] School of Computer Science, University of Windsor, Windsor, Ontario, Canada N9B 3P4 \\ *Corresponding Author: arifs@uwindsor.ca
}

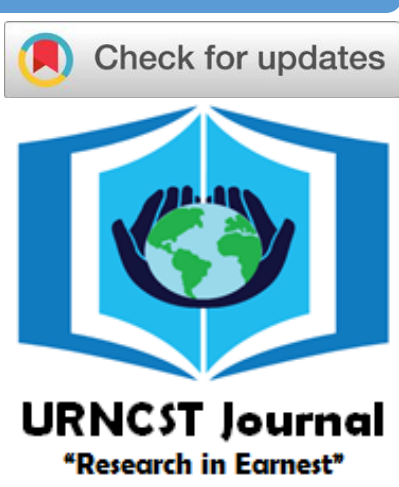

\begin{abstract}
This project develops a prototype of data management system for Palliative care systems. The current demo focus on demonstrating how their questionnaires can be conducted, stored and analyzed in a single website using latest NodeJS and MongoDB technologies. This web application provides a modern UI interface with easy-to-use features for hospice administrator, social workers and candidate patients. Hospice administrator can create new questionnaire, edit existing questionnaire template and analyze all the questionnaire information. Social workers can see their patients and corresponding questionnaire, creating or editing a questionnaire for his patients. Candidate patients, after being invited to the system, can also use the system to complete their own questionnaire. This new system will not only help improve the quality and efficiency of the current questionnaire interview process but will also help the Hospice staff to make better use of the information collected from the questionnaire. Information retrieval and analysis will be much easier and accurate with the new system, and various sentimental analysis tools can be applied to better understanding the patient's information.
\end{abstract}

Keywords: palliative care; DBMS; care management; data storage; NoSQL

\section{Introduction}

This project primarily is designed for handling and managing of medical and personal information of the hospice patients. We design and produce a computerized database management system and a web application to transform Hospice patients' paper-based /word document data into an electronic version. The application provides a user-friendly graphical interface to administrator, caregivers and patients to retrieve, change or, add new information.

In addition to user profile management, and user access management subsystem, the application embeds a web survey system for Hospice including functions such as designing and completing the questionnaire, storing and retrieving the questionnaire information with analytics functionalities.

Its goal is to replace the current manual interview questionnaire completing process and store all the information in the central database. The application can be easily accessible in any smart portable electronic device such as phone, laptop or tablet.

\section{Importance of the Problem}

The questionnaire completed during the interview process is about 20-pages long and contains a lot of important information about candidate patients. Hospice staff use the information in the questionnaire to determine what help to offer to the patients and track the progress. However, this vital information is not stored and managed in a unified single version manner.

Currently, all questionnaires are saved in word document format, that each patient has a word document file, shared by the social workers who did the interview. The information thus is scattered, could be redundant and making strategic decisions based on these poor qualities of data can be very time-consuming. Last but not least, there is lack of security measures on protecting the data. Our new system is trying to resolve all these challenges and difficulties.

\section{Methods}

This project follows REST architectural pattern [1]. RESTful APIs are application programming interfaces that adhere to the architectural style of REST architectural pattern. All user interface is written in HTML and styled by CSS using Bootstrap template. This enables us greater flexibility for software development yet a sustainable manner. REST pattern also supports the cloud architecture intrinsically, which provides greater extension possibility for our future system development.

The project is mainly developed in JavaScript programming language. The entire server is written in JavaScript. We have adopted Node.js as our runtime environment. As asynchronous event-driven, Node.js is a 
very good option for developing a scalable real-time application [2]. It is also integrating front-end and back-end to a more uniformed way to make the whole application more lightweight.

MongoDB is a document database with the scalability and flexibility that you want with the querying and indexing that you need [3]. MongoDB is selected for building the database because it is simple, dynamic and scalable. It also provides high performance, high availability and automatic scaling. The majority of data that need to be saved are semi-structured information - the answers to the survey question. There are large texts and not following a rigid schema. MongoDB is the ideal choice for storing such data compared to traditional SQL databases.

We selected Python for the data analysis part because it provides various built-in libraries for data analysis such as different classification algorithms and libraries for natural language processing.

Multiple surveys can be added and updated, and the result will be saved to the MongoDB. Only the administrator can edit the survey template or design a new survey. All required survey-related functions are implemented by embedding the open-source SurveyJS library [4]. It provides a rich JavaScript library to integrate the survey and survey builder into our system.

\section{Setup}

The enter point of the system is the main website. Upon click on the login button, the user will need to type in the username and password. After successful authentication, the user will be brought to the dashboard belongs to his/her user access. Figure 1 shows the administrator's main page after successful login. We have successfully implemented the listed functions above including managing staff and patient's information (Figure 2), creating new surveys (Figure 3) and access all the information within the system. The website has been designed in a unified style that to give all users a welcoming feel by adopting Bootstrap styling reference.

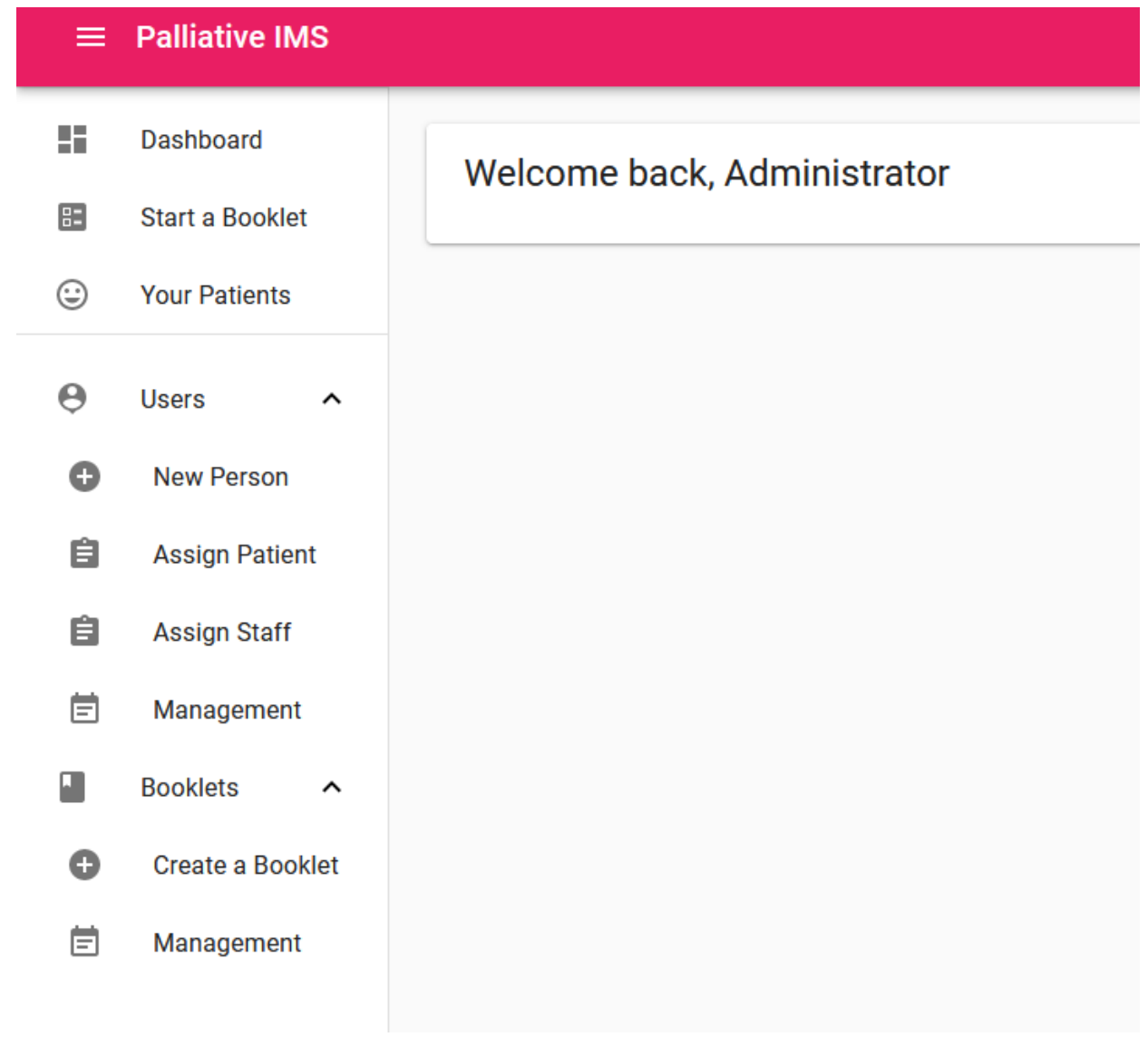

Figure 1. Admin main page 
UNDERGRADUATE RESEARCH IN NATURAL AND CLINICAL SCIENCE AND TECHNOLOGY (URNCST) JOURNAL

Read more URNCST Journal articles and submit your own today at: https://www.urncst.com

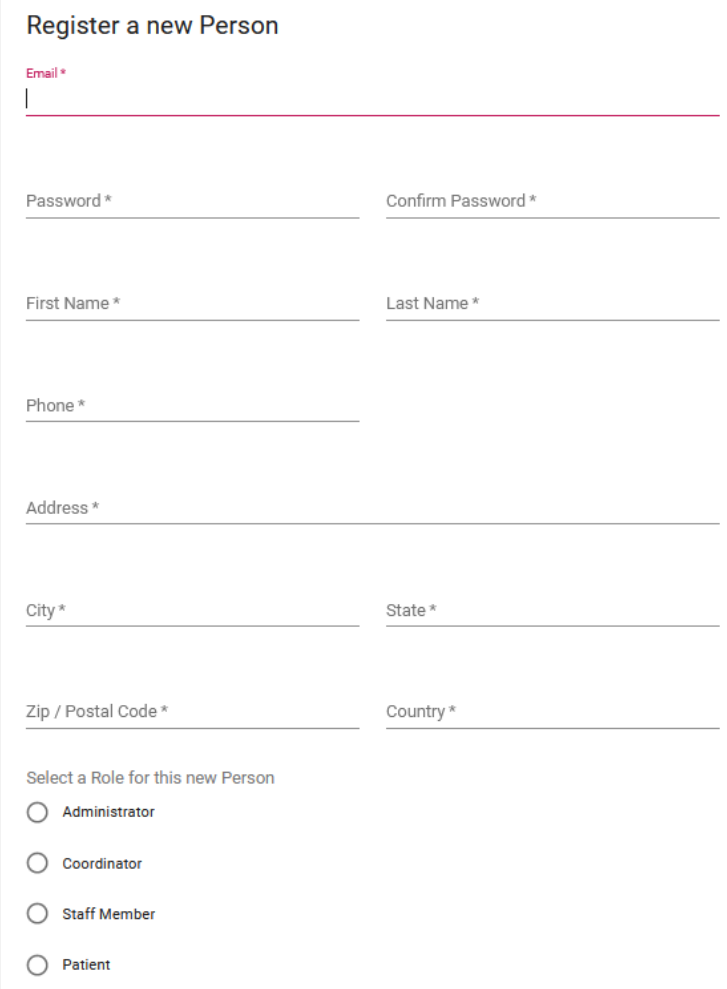

Figure 2. Add user information and assign a role

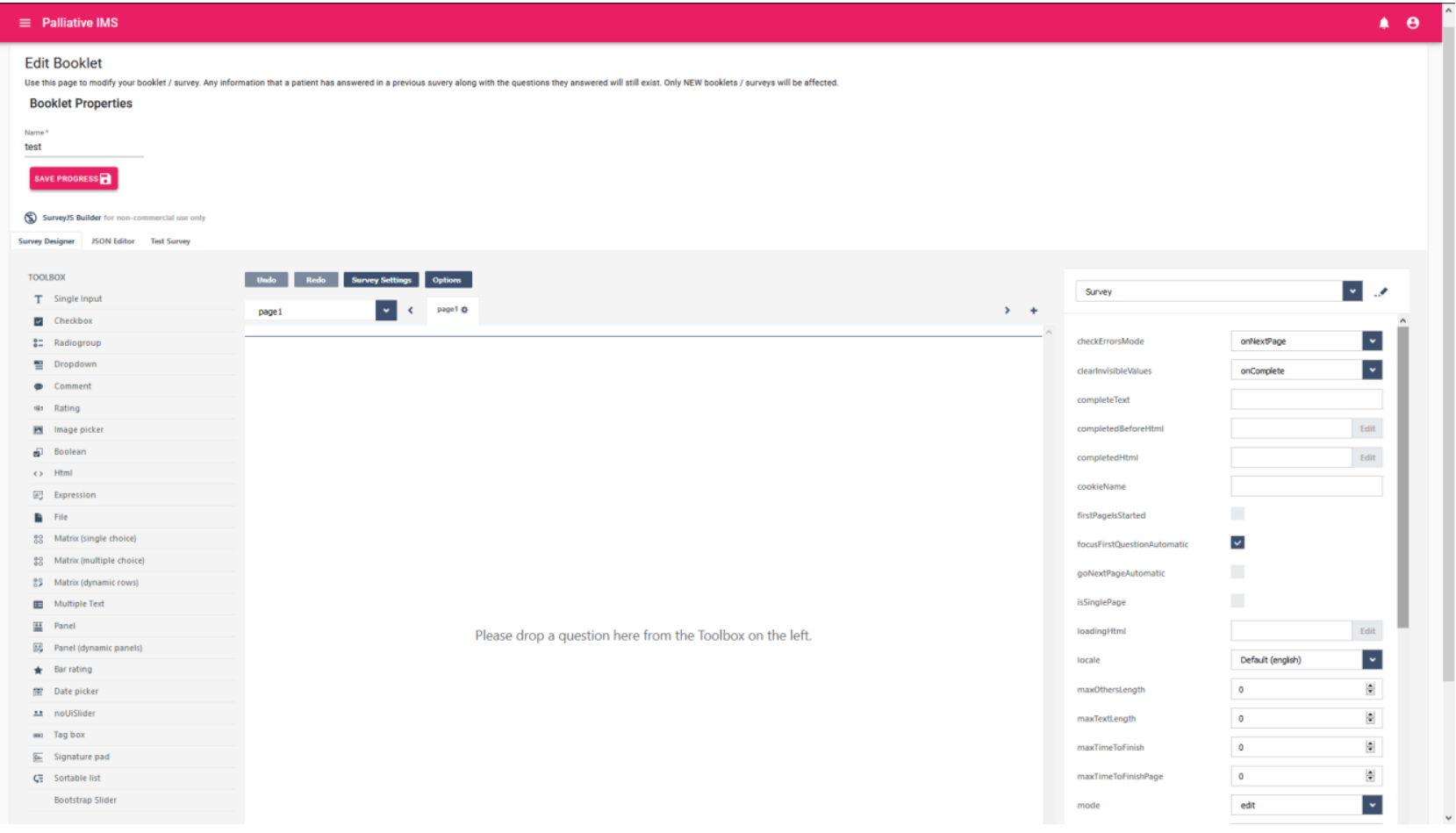

Figure 3. Creating multiple customized survey 
UNDERGRADUATE RESEARCH IN NATURAL AND CLINICAL SCIENCE AND TECHNOLOGY (URNCST) JOURNAL Read more URNCST Journal articles and submit your own today at: https://www.urncst.com

\section{Conclusion}

Overall, we have successfully implemented a web survey system for Hospice of Windsor including functions such as user registration and user access management, designing and completing the questionnaire, storing and retrieving the questionnaire information with analytics functionalities. In the future, we are going to improve the GUI features and provide data analytics services.

\section{List of Abbreviations}

API Application Programming Interface

CSS Cascading Style Sheet

DBMS Database Management Systems

HTML Hypertext Markup Language

REST Representational State Transfer

NoSQL not only SQL

SQL Structured Query Language

\section{Conflicts of Interest}

The author(s) declare that they have no conflicts of interest.

Ethics Approval and/or Participant Consent

This study did not require ethics approval.

\section{Authors' Contributions}

SA: made contributions to the design, analysis and implementation of the software, drafted the manuscript, and gave final approval of the version to be published.
TL: made contributions to the design, analysis and implementation of the software, drafted the manuscript, and gave final approval of the version to be published. PMZ: made contributions to the conception and design of the study, the acquisition, revised the manuscript, and gave final approval of the version to be published.

\section{Funding}

This study was not funded.

\section{Acknowledgements}

The project has been conducted under the supervision of Windsor Essex Compassion Care Community (WECCC).

\section{References}

[1] Spring. 2018. Understanding REST. Retrieved Nov 29, 2018 from https://spring.io/understanding/REST

[2] NodeJS. 2018. About Node.js. Retrieved Nov 29, 2018 from https://nodejs.org/en/about/

[3] MongoDB. 2018. What is MongoDB. Retrieved Nov 29, 2018 from https://www.mongodb.com/what-ismongodb

[4] SurveyJS. 2018 What is SurveyJS. Retrieved Nov 29, 2018 from https://surveyjs.io

\section{Article Information}

Managing Editor: Jeremy Y. Ng

Peer Reviewers: Ikjot Saini, Kalyani Selvarajah, Mahreen Nasir Butt

Article Dates: Received Aug 07 19; Published Sep 0519

\section{Citation}

Please cite this article as follows:

Arif S, Li T, Zadeh PM. Palliative care management system. URNCST Journal. 2019 Sep 05: 3(8).

https://urncst.com/index.php/urncst/article/view/151

DOI Link: https://doi.org/10.26685/urncst.151

\section{Copyright}

(C) Saman Arif, Tong Li, Pooya Moradian Zadeh (2019). Published first in the Undergraduate Research in Natural and Clinical Science and Technology (URNCST) Journal. This is an open access article distributed under the terms of the Creative Commons Attribution License (https://creativecommons.org/licenses/by/4.0/), which permits unrestricted use, distribution, and reproduction in any medium, provided the original work, first published in the Undergraduate Research in Natural and Clinical Science and Technology (URNCST) Journal, is properly cited. The complete bibliographic information, a link to the original publication on http://www.urncst.com, as well as this copyright and license information must be included. 


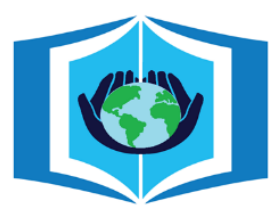

\section{URNCST Journal \\ "Research in Earnest"}

\section{Funded by the \\ Government of Canada}

\section{Canadà̀}

Do you research in earnest? Submit your next undergraduate research article to the URNCST Journal!

| Open Access | Peer-Reviewed | Rapid Turnaround Time | International | | Broad and Multidisciplinary | Indexed | Innovative | Social Media Promoted |

Pre-submission inquiries? Send us an email at info@urncst.com | Facebook, Twitter and LinkedIn: @URNCST

Submit YOUR manuscript today at https://www.urncst.com! 